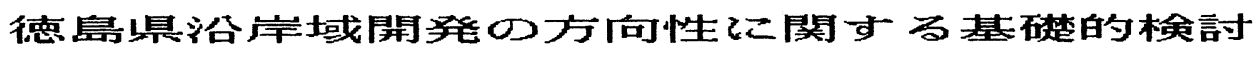

\author{
徳島大学工業短期大学部 正会員 村上仁士 \\ 徳島大学工業短期大学部 正会員 細井由彦 \\ 徳島大学工業短期大学部 正会員 上月康則
}

1. 緒 言

昭和62年の第 4 次総合開発計画で四国の開発方向が示され、同年総合保桼地域整備法が施行されるにおよび、徳島 県でも大規模リゾート地域整備構想が発表された。その整備テーマは『ヒューマン・リゾートとくしまの海と森』て ある。このうち、徳島県の沿岸域については「海のリゾート」として一体的に整備しようとするむのである。いうま でもなく、沿岸域の開発計画の実施にあっては、各地区の持つ個性を十分生かしつつ、広域的な視野で沿岸の有効利 用、環境保全、住民の意志が反映された開発がなされなければならない。

本研究は、こうした立場加ら、研究の第一段階として、徳島県沿岸各地区の特性を明確にして、個々の地区の開発 の可能性を探るのではなく、四国全体あるいは近隣沿岸域の社会環境や自然環境を比較しつつ、徳島県沿岸域の実態 把握に努めようとするものである。ここでは、徳島県の県民性などについても考察し、県民の潜在的欲求を堀りおこ すような、沿岸域の開発の方向を示す基礎資料を得ることにとどまっている。なぜならば、徳島県の海岸線は地形的 にむ、また自然条件む場所的にかなり異なり、個々の沿岸地区の特性を生かした開発を考える前に、むう一段大きな スケールで沿岸域の特性を位置づけておく必要があるからである。

\title{
2. 徳島県沿岸域の開発基盤
}

沿岸域の開発の方向を策定するには、県の持つ特性を把握すると同時に、四国を中心とした近隣の県および全国的 視野からみた徳島県の位置付けをしておくことが必要である。そこて、徳島県の県民性・社会環境・自然環境などにつ いて、全国レベル、および、四国レベルの視野で考える。また、今後、関西国際空港などの開港によって和歌山県の 影響をおおきくうけると考えられるため、和歌山県も比較対象とすることにして、徳島県の特性および開発基盤につ いて調べた。

\section{$2-1$ 徳島県沿岸域の概況}

徳島県のP Rに”青い海”、”海岸線に恵まれている” といった表現がよく用いられているが、徳島県の海岸線延 長は383.6kmで、四国全体の11.2\%にしか過ぎない。 全国順位でも30位と、特别海岸線に恵まれているわけでも ない。しかしながら、蒲生田岬一日ノ岬（和歌山県）を結 ぶ線をボトルネックとして、南は太平洋に面した起伏の激 しい海岸線美と多くの入り江を持ち、日本有数の磯釣りの メッカとなっているほか、雄大な海洋性レクリエーション 基地となりうる可能性を持っている。しかし、太平洋に面 するこの沿岸は、かって、津波、高潮、高波災害などに見 舞われるなど、常に、厳しい自然条件にさらされている。 一方、その北岸の海岸は、日本でも有数の良好な水質を有

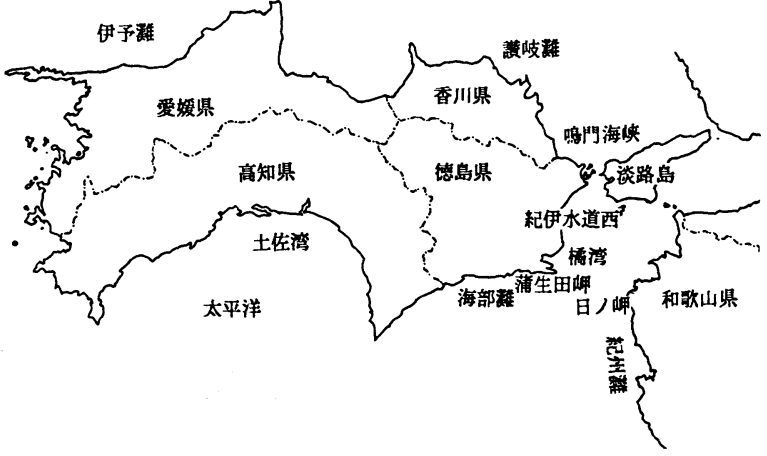

図-1四国および和歌山県の沿岸域 する北ノ脇海水浴場を始め、四国の松島と呼ばれる風向明美な橘湾、徳島の玄関小松島港、さらに世界に誇る洞て知 られている鳴門海峡までの沿岸、さらに瀬戸内海、播店灘に面する沿岸と、実にバラエティーに富んだ沿岸域を形成 している。また、和歌山県とは東方50kmの距離で沿岸が向かい合っている。

2-2 関西圈の中の徳島県と徳島県民の意識特性

a）関西圈の中の徳島県

関西圈の中で徳島県および高知県は生鮮食料品の供給基地という役割を担っている。徳島県は京阪神へは至近の位 置にあるということもあり、生鮮食料品の関西圈での販売数量、販売金額は、ともに全国一である。さらに、大鳴門 橋に続き明石海峡大橋が完成すると、徳島県は神戸と100分で直結できることになることなり、生鮮食料品の供給基地 としての役割就益々重要になるものと考えられる。また、大阪泉南沖の建設される関西国際空港は、徳島県と海上70 $\mathrm{km}$ m距離にあることや、四国絴貫自動車道や徳島空港の本格的ジェット化など、本地域を取り巻く大規模な基盤整 備が着実に推進されれば、地域の飛躍的発展が期待でき、早急な基盤整備が望まれる。

b）徳島県民の意識特性

昭和53年にNHKが行った『全国県民意識調查』"によると、德島県民は全国的にも保守的、政治に対して無関心、金 
銭中心の実力主義という意識特性を持っていることが明らかにされている。近隣県の県民性と比較してみると、愛媛 県民、香川県民は保守的という点で徳島県民と似かょっているが、高知県民は反権威的であり、四国の中でも特異で 南ると言える。一方、平成元年に徳島県が行った『県民世論調查報告書』2)によると、徳島県民の は現在の生活に満足し、住みよいと考えているものの、交通網に関しては5割の人々が不満であると考えている。こ れらの県民性は県南部にいくに従って強調される傾向にあり、高速道路や明石海峡に対する期待感も県北部に比べて 低くなっている。すなわち、これらの地区で新しく何等かの開発を行うことは、現在の生活環境を変えることになり、 開発を行うことは難しいことになる。したがって、今後、徳島県が沿岸域の開発を進める際にも、これらの県民性を 十分に考慮することが重要である。

\section{$2-3$ 徳島県の社会環境}

徳島県の社会環境を把握しておくために、人口・人口密度・人口增加率·総生産·総面積・上下水道普及率・一般道路実 延長および舗装率・観光地の人り込み客数などについて調べた。

a) 人口

徳島県の人口は 83.6 万人（昭和62年）、全国順位43位、四国抒 よび関西圈の中で最も少ないものの、人口增加率（昭和55〜60) は1.2\%と全国順位37位であり、高知県、和歌山県よりも高い。 人口密度は 201 人 $/ \mathrm{km}^{2}$ 、全国順位30位で高知県を除く他の近隣県よ りも低い。生産年粗人口割合は、66.3\%（全国順位23位）である。

徳島県の人口の分布を吉野川流域、那賀川流域および徳島県沿 岸別で見てみれば、人口增加が著しいのは、徳島市を中心とした 県北地域纪限られており、他の地区では、横ばいもしくは、減少 している。特に、吉野川および那賀川の上流域の地区では過疎化 が進み、沿岸域では阿南市以南に行くほど人口の減少が認められた。 四国の高龄化現象は全国のそれよりも10年進んでいると言われて おり 、全国の高齢化県順位は、徳島県が 8 位、高知県が 2 位、 香川県が 7 位、愛媛県が16位となっている。徳島県の医療状況は、 医師数㧍よび医療扶助人員はそれぞれ全国順位 2 位および 3 位、

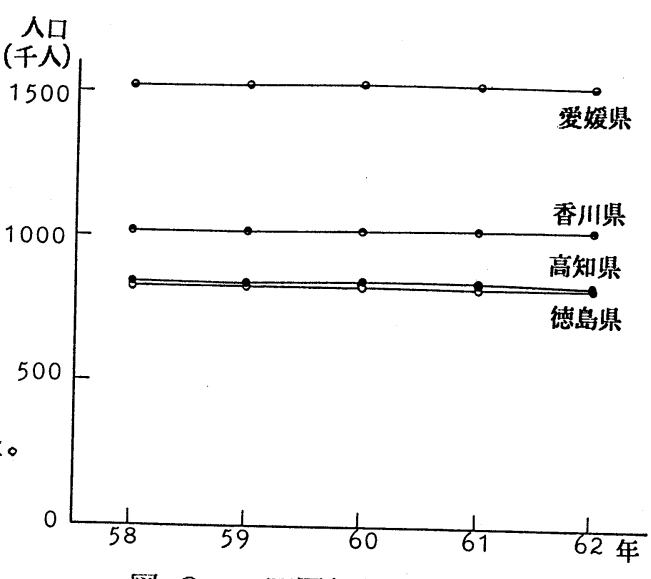

図-2四国各県の人口動態

一般病院数、老人ホーム数はそれぞれ4位および 2 位である。このように、高軨化社会を迎えるにあたって、医療は 全国的に見ても充実されていると言える。現に、徳島県は21世紀を展望し、基本理念を「健康のメッ力徳島の創世」 に置いた、長期ビジョン” HOT (Heal thy Our Tokushima)構想”をまとめ、2025年を見据えていることもあり、沿岸 域の開発もそれに沿った保養・休養の基地などの方向も考えられる。

b) 産業

産業3部門別就業者の特性は第一次産業の就業者は滅少し、第3次産業のそれは增加の傾向を示す。この傾向は、 全国的にむ、四国でも以下のように同様である。第 1 次産業は、年々減少し昭和 60 年では四国全域 $20 \%$ 末满となって いるが、徳島県の場合は $15.4 \%$ 、全国順位14位と全国レベルでは高い值であるといえる。また、耕地 $10 \mathrm{a}$ 当り生産農 業所得は全国順位6位と四国の中では高知県に次ぐ所得である。第 2 次産業は、昭和50年比までは增加していたがそ れ以降わずかながら減少し、今や徳島県は $30 \%$ 程度となっている。これらの産業に対して、第3次産業は增加の一途 をたどり四国の全県で50\%以上にも達している。以上のように、全国的にみると徳島県は産業・経済の中に占める農 業の割合は大きいと言える。また、県民が期待する 90 年代のリーディング産業には、65\%の人がバイ才関連産業を举 げている4)。この産業は、先に述べた県の構想” HOT”沿っていることから、今後、発展、成長する可能性があ ると考えられる。

c）総生産・一人当りの県民所得

四国の総生産額は10兆円である。このうち徳島の占める額は、1.64兆円、全国順位44位にとどまっており、和歌山 県を含む四国の3県と比べると高知県（1.58兆円）を除いた他の県より低い額である。また、一人当りの県民所得（ 174万円）は、全国順位33位（全国平均218万円）であり、近隣4県と比べると香川県よりは低いむのの他の3県より は高い額である。しかしながら、增加率は、3.7\%と全国順位30位（全国平均 $5.6 \%$ ）と近隣 4 県の中でも最も高い値 を示し、消費者物洒指数（昭和60年）沙全国順位33位、持ち家割合注20位、乗用車所有量は10位と、個々の県民は全 国レベルでみると豊かな生活を送っていると言える。また、県民の5割の人々か90年代は余暇を楽しむ時代であると 考えている3 ものの、急速な徳島県のリゾート化には慎重な見方をしている4)ことから、沿岸部の開発は県民む低価 格で余睱を楽しめる施設を整備すると言った方向が県民の需要に答えていると思われる。

d）上下水道普及率

德島県の上水道の普及率㳉 $89.3 \%$ 、全国順位（全国平均、93.6\%) 29位である。一方、下水道の普及率注、 $29.3 \%$ と高知県 $(19.8 \%)$ 、和歌山県 $(9.6 \%)$ に比べると高い割合であるが全国平均（59.1\%）からみるとまだまだ低い。 
なお、この原因の一つは、四国山眽南部は降雨量が多く、雨水排除のための都市下水路の整備に力をいれているため であり、他の地域と直接比べることはできない。しかし、公共用水域の水質保全の面からも、沿岸域の開発にとって ま、清浄な水の持つイメージが重要であることから、早急な下水道の整備が望まれる。

\section{e ） 観光客人り込み数関係}

徳島県の観光客の $85.6 \%$ は県外客であり、そのうち $50.2 \%$ は関 （千人）

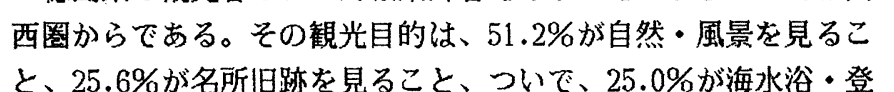
山などスポーツを楽しむこととなっている。昭和60年に大鳴門橋 が、昭和63年に瀬戸大橋がそれぞれ開通したが、図-2亿示した四 国各県の観光客の経年変化からわかるように、昭和60年の大鳴門 橋の開通効果は徳島県でしか見られないのに対して、昭和63年の 瀬戸大橋の開通効果は、香川県をはじめとして、四国全域でみら れた。このことから、大鳴門橋が開通しても、昭和61年の徳島県 の観光客数は隇少していることでもわかるように、大鳴門橋の魅 力だけでは徳島県へ観光客を魅き付けることはできないようである。 しかしながら、四国と本州を結ぶルートの選択枝が多くなれば、 四国の観光客の入り込み数潽化すると考元られる。また、観光 目的の大半は自然・風景を見るこどりになっているが、今後、自 然・風景を見るという単調なもので観光地化されるかどうかは疑 問である。徳島県観光調查報告所によると、徳島県を訪れた人は、 今後観光に全年龄層の人が自然風景や保養・休養を望み、60才以 上の人は特に名所旧跡を望んでいる5)。沿岸域の開発注は、これ

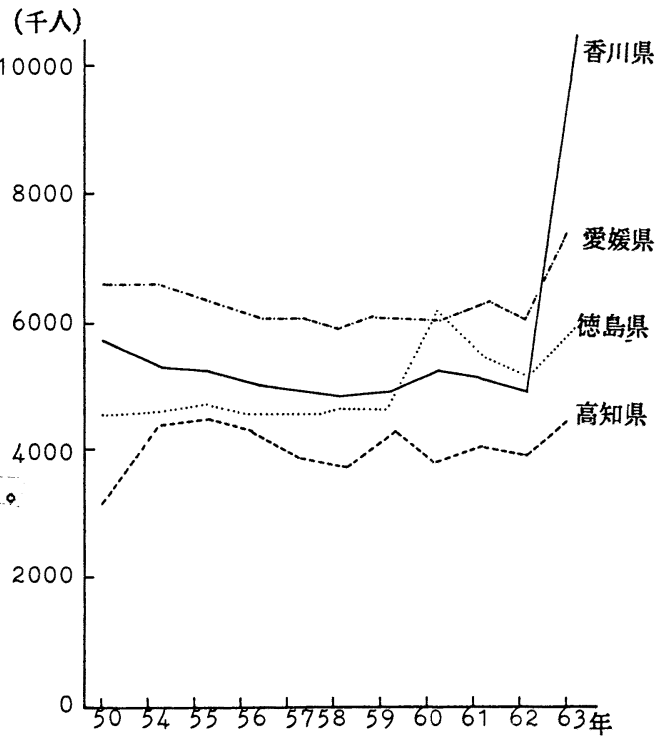

図-3四国各県の観光客動態 らのことを十分に考虑することが必要である。

f）プレジャーボート数

四全総の中で、四国地方は海洋性豊かな自然を生かした開発が望まれているが、マリンスポーツは今後の開発の方 向を占う一つの大きな指標であろう。マリーナなどの施設は、全国的にもまだ十分整備されていないが、徳島県のプ レジャーボート数は2,692隻あり、四国の17.6\%にあたる。なお、四国にはプレジャーボートが15,240隻（昭和60年） あり、全国の16.4\%を占める。これは、九州地方の $24.2 \%$ 、中国地方の $23.2 \% に$ 次ぐ割合であり、今後は全国的にむ、 四国においても、レジャーブームとあいまって、さらに増加する傾向がうかがえる。 2 -3徳島県の自然環境

a) 気温・海水温 和歌山を含めた近隣 5 県の気温を理科年表 58 年度版により調べ てた結果、高知県の足摺岬が冬期で $2 \sim 3{ }^{\circ} \mathrm{C}$ 、他の地域より高い ことを除くと、他は大きな違いはみられなかった。気温はりゾー 卜開発にとって重要な要素となるため、徳島県の月平均気温と一 般的にリゾート地と言われている地域の気温を比べた。その結果 を図-3に示す。この図から、徳島県は冬期に他の地域より気温が

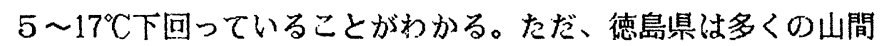
部からなっており、このデータが必ずしも沿岸域の気温を表して いるとは言えず、より詳細なデータを用いて評洒することが必要 であると思われる。一方、紀伊水道側の德島沿岸部の海水温は、 冬期、夏期ともに太平洋側に比べると $3^{\circ} \mathrm{C}$ 程低く、2月で17〜18

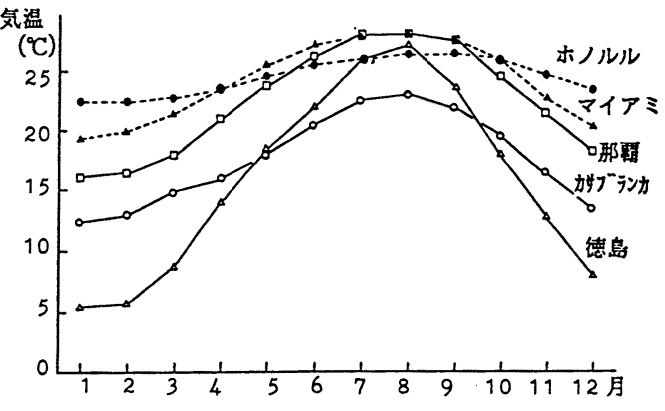

图ー1＼cjkstart徳島県およびリゾート地域の気温 ${ }^{\circ} \mathrm{C}$ であった。このように、海洋性のレクリエーションに対する適、 不適を、気温・海水温のみから評価すると、冬期代やや難点がある と言える。

b) 雨量

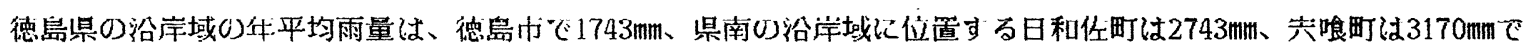
あり、高松市の $1199 \mathrm{~mm}$ 、松山市の $1337 \mathrm{~mm}$ よりはるかに多い。また、高知市は $2666 \mathrm{~mm} 、$ 足摺岬は $2473 \mathrm{~mm} 、$ 室戸山甲は2 2524 mmと徳島県沿岸よりさらに雨量が多い。四国山脈の南部に位置するところでは、全国平均雨量の $1950 \mathrm{~mm}$ えている。時期的には、梅雨や台風の時期に集中しているために、水資源が豊富であるという反面、洪水や高潮の危 険性が他の地域よりむ多い。このことは、徳島県南部の沿岸域を開発する際に流、安全面に対して万全の対策が必要 であることを意味している。 
d）天候

海洋性レクリエーション地としての適性を考える上で、快晴日、墨日、夏日、真夏日などは重要な要因である。 日照時間について、全国観測地点80地点のうち、四国全域を含めた50\%が2000時間をこえている。しかし、海外のリ ゾート地と言われている地域の日照時間は月平均240時間以上であり、1日当りの日照時間で比較すると徳島県のそれ は、約 2 時間少なかった。 徳島県の快晴日と显日の合計、すなわち非降雨日は152日であり、香川県、愛媛県と大差 はない。徳島県の真夏日と夏日の合計は、161日と四国4県の中で最も少ないものの、全国の中では高い水準にあった。 これらのことから、徳島県の沿岸で海洋性レクリエーションを行う際に天候が障害となることはないと考えられる。 e) 海岸特性

沿岸の水筫は、環境基準の類型で言えば小松島港のB、富岡港のCを除いた県内の沿岸域はAである。県北に位置 する、小松島沖で測定された1974年〜1987年の有義波高（H 1/3）、周期（T1/3）の出現率を調べると、H 1/3は0.2 5 0.5mが最も高く $50.9 \%$ あっった。ついで、0.25m未满が27.0\%と多い。また、周期については、 $\mathrm{T} 1 / 3=3.0 \mathrm{~s} \sim$ $4.0 \mathrm{~s}$ が最む高く $25.9 \%$ あっった。ついで、 $4.0 \mathrm{~s} \sim 5.0 \mathrm{~s}$ が21.6\%と多い。また、県南に位置する蒲生田岬においてす、 1974年 1981年にかけて有義波高（H1/3）と周期（T 1/3）功測定された。その結果、最む出現率の高い有義波高（ $\mathrm{H} 1 / 3$ ）は、0.25m未满が53.4\%、ついで、0.25 0.5mが22.1\%であった。周期は、 $\mathrm{T} 1 / 3=3.0 \mathrm{~s}$ 末满（68.4\%）が 最も出現率が高かった。

瀬戸内側の香川県には46力所、愛媛県には49力所、太平洋倒の高知県には11力所の海水浴場があるが、上に述べた ような海岸特性をもつ徳島県の沿岸には海水浴場は 8 力所しかなく、四国の中で最も少ない。なお、全国的にみても 10力所を下回る県は徳島県を含めて4県しかない。この原因の一つとして、徳島県の海岸線は際だって長くない上に、 強い離岸流が存在し、遊泳禁止区域となっている海岸があるためと考えられる。

\section{3. 徳島県沿岸の開発ポテンシャルの評価}

開発利用空間としての沿岸域の評価・選定手法の確立そのものが重要な研究課題であり、現在は確立されたものは ないが、ここでは宇多ら6゙7の評価方法にならうことにした。以下にその方法を述べる。

3-1＼cjkstart開発ポテンシャルの評価方法および沿岸域の類型化

a) 気象条件（気温・水温条件）

気温および水温の評価基準となる值を、海洋性レクリエーションの適性条件を参考にして、その評価を 5 段階に区 分し、それぞれの区分の評洒点を定めている。また、天候に対する指標として日照時間を用い、世界の著名リゾート 地の日照時間は、1 日平均 8 時間以上の值を示すところが多い。したがって、1 日の平均日照時間が 8 時間であると すれば、月平均日照時間は240時間となる。これを最適な条件として、表-1のように設定し、この評価点を基に沿岸 表- 1 気象条件の評価方法

\begin{tabular}{|c|c|c|c|c|c|}
\hline \multicolumn{2}{|c|}{ 気温・水温条件 } & \multicolumn{2}{|c|}{ 日 照 時 間 } & \multicolumn{2}{|c|}{ 快 適 性 } \\
\hline 評価点 & 評洒基準 & 評価点 & 評価基準 & 評洒点 & 評価基準 \\
\hline 0 & $<10^{\circ} \mathrm{C}$ & 0 & $<120 \mathrm{hr}$ & 0 & $<15^{\circ} \mathrm{C}$ \\
\hline 1 & $10 \sim 15^{\circ} \mathrm{C}$ & 1 & $120 \sim 180$ & 1 & $15 \sim 20^{\circ} \mathrm{C}$ \\
\hline 2 & $15 \sim 20^{\circ} \mathrm{C}$ & 2 & $180 \sim 240$ & 2 & $20 \sim 30^{\circ} \mathrm{C}$ \\
\hline 3 & $20 \sim 24^{\circ} \mathrm{C}$ & 3 & $\geqq 240 \mathrm{hr}$ & 0 & $\geqq 30^{\circ} \mathrm{C}$ \\
\hline 4 & $\geqq 24^{\circ} \mathrm{C}$ & & & & 开する。 \\
\hline
\end{tabular}
を表-2にしたがって類型化している。

b) 波浪条件

夏期および通年において波高が1.5、1.0、0.5m以下となる場合の出現頻度と、 各海洋性レクリエーションに望まれる波高の条件から表-3のように波浪条県の評 価方法を求め、波浪による沿岸の類型は、表-4のように3種類の波高の夏期およ び通年に置ける出現頻度に対する評価点の合計から決められている。 表-4 波浪条件の類型化

\begin{tabular}{|c|c|}
\hline 類型 & \multicolumn{1}{|c|}{ 類 型 基 隻 } \\
\hline $\mathrm{A}$ & 通年・夏期のどちらも50\%以上の評価となる沿岸 \\
\hline $\mathrm{B}$ & 通年の評価点だけが $50 \%$ 以となる沿岸 \\
\hline $\mathrm{C}$ & 夏期の評価点だけが $50 \%$ 以となる沿岸 \\
\hline$D$ & 通年・夏期どちらも50\%未满の評洒点となる沿岸 \\
\hline
\end{tabular}
表- 2 気象条件の類型化

\begin{tabular}{|c|c|}
\hline 類型 & 類 型 基 隻 \\
\hline $\mathrm{A}$ & 評価比が $50 \%$ 以上となる沿岸 \\
\hline $\mathrm{B}$ & 評価比が $35 \%$ 以上 $50 \%$ 末満となる沿岸 \\
\hline $\mathrm{C}$ & 評価比が $35 \%$ 未満となる沿岸 \\
\hline
\end{tabular}
なお、評価比は、1 年間の評価点合計の満点 に対する割合である。

c)交通機関の整備状況

沿岸域周辺の交通機関の利便性を知るために、鉄道主要駅数、インターチェンジ数、主要道の割合を取り上げ、交 通機関の整備状況の評価方法は表-5のようひ定めらている。 
表- 5 交通機関の整備状況の評価方法

\begin{tabular}{|c|c|}
\hline 項 & 方 \\
\hline 鉄道主要駅 & 沿岸から半径 $40 \mathrm{~km}$ 圈内にある主要駅の数の各沿岸延長に対する割合 \\
\hline 付夕-チrジ゙数 & 沿岸から半径 $20 \mathrm{~km}$ m圈内にある付夕-チェンジ数の各沿岸延長に対する割合 \\
\hline 主要道の割合 & 各沿岸に隣接する県の主要道（国道、地方主要道）の総延長と県の面積の比 \\
\hline
\end{tabular}

交通の整備状況は、次の 2 つの条件を考え、沿岸を分類している。すなわ 表-6 交通機関の整備状況の類型化 ち、条件 1 は鉄道と高速道路の整備状況の分布は類似することから、主要類型 類 型 基 準 駅とインターチェンジのどちらか一方が、 $1 \mathrm{~km}$ たり0.03個以上ある沿岸、 条件 2 は主要道の割合が $1 \mathrm{~km}^{2}$ あたり $1.5 \mathrm{~km}$ 以上ある沿岸と設定し、これ を基に沿岸を表- 6 に示す 4 つに分類している。

d）利用者の市場の有無と観光資源からみた評価

\begin{tabular}{|c|l|}
\hline 類型 & \multicolumn{1}{|c|}{ 類 型 基 準 } \\
\hline $\mathrm{A}$ & 条件 1，2の両方を満たす沿岸 \\
\hline $\mathrm{B}$ & 条件 1のみを満たす沿岸 \\
\hline $\mathrm{C}$ & 条件2のみを満たす沿岸 \\
\hline $\mathrm{D}$ & どちらの条件も満をさない沿岸 \\
\hline
\end{tabular}

開発地としてのポテンシャルを計るために、都市数と史跡・名跡数を調べ、表-7に示した方法により評価し、表-8に よって分類 表- 7 利用者の市場の有無と観光資源からみた評価方法 している。

\begin{tabular}{|c|c|}
\hline 項 $\quad$ 目 & 評 洒 方 法 \\
\hline 都 市 数 & $\begin{array}{l}\text { a) 沿岸から } 100 \mathrm{~km} \text { 圈内にある人口 } 15 \text { 万人以上の都市数の沿岸延長に対する割合 } \\
\text { b) 沿岸から } 100 \mathrm{~km} \text { 圈内にある人口 } 100 \text { 万人上の都市数の沿岸延長に対する割合 }\end{array}$ \\
\hline 史跡・名跡数 & 沿岸に隣接する各県の史跡名勝数の面積に対する割合 \\
\hline
\end{tabular}

分類方法は次の 2 条件から定めている。条件 1 は都市数が沿 岸域 $1 \mathrm{~km}$ あり0.05個以上であること条件 2 は史跡·名所数が 面積 $10 \mathrm{~km}^{2}$ あたり0.05個以上であるこである。 e)レクリエーション施設数からみた開発地の分類

宇多らの観光地としてのポテンシ ヤルの評洒方法に加えて、より詳細に 以下のようにレクリエーション施設 を用途別に調べ、沿岸域を分類した。 レクリエーション施設を山岳に関す るもの、海洋に関するむの、レジャ

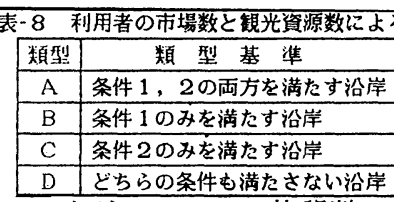
表-9 レクリエーション施設数による分類

\begin{tabular}{|c|c|c|}
\hline & 評価方法 & 類型方法 \\
\hline 山岳関係 & 各県の林野面積に対する割合 & 全国の全総数を面積や距離て \\
\hline 海洋関係 & 各県の沿岸延長に対する割合 & 各項目で割った値を全国平均 \\
\hline Lジャー関係 & 各県の可住地に対する割合 & 値とし、これより上回るもの \\
\hline 観光資源 & 各県の総面積の対する割合 & をA、下回るものを B とする \\
\hline
\end{tabular}
ーランド・動物園などのレジャーに関するもの、および史跡・名勝に加えて国宝をむ含めた観光資源に関する 施設数を調べ、開発地を表-9のように分類した。

3.2 徳島県沿岸の開発ポテンシャルの評価

徳島県沿岸域の開発ボテンシャルを評価を行う前に、建設省海岸統計における海岸区分にならい四国沿岸域を図 5 のように区分した。このうち、宇多ら ${ }^{617)}$ はすでに海部灘、土佐湾について評価を行っているが、本研究では、徳島 県沿岸に含まれる伊予灘、譛岐阿波、紀伊水道西の沿岸域について、同様に開発評価とその方向性について検討を行 った。その結果を表-10に示す。なお、宇多らの結果の一部む比較するために載せた。以下この表を用いて考察する。

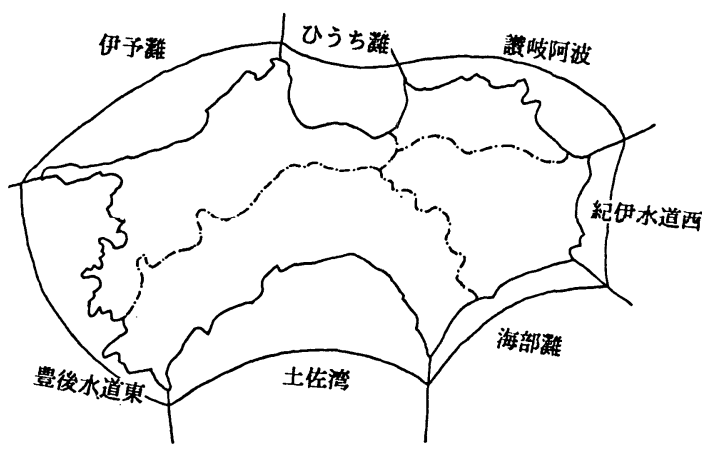

図-5四国沿岸域

\begin{tabular}{|c|c|c|c|c|c|}
\hline \multicolumn{3}{|c|}{ 表-10 } & \multicolumn{3}{|c|}{ 沿岸分類表 } \\
\hline 海域 & & 気象 & 波 浪 & 交 通 & 開 発 \\
\hline \multirow{3}{*}{ 伊予灘 } & 評点 & 46.0 & 夏 80.7 & 10.000 & (1) 0.017 \\
\hline & & & 通 86.7 & 駅 0.036 & (2) 0.000 \\
\hline & 類型 & B & $\mathrm{A}$ & B & D \\
\hline \multirow{3}{*}{ 譛岐灘 } & 評点 & 47.1 & 夏 80.0 & 10.007 & (1) 0.013 \\
\hline & & & 通 86.7 & 駅 0.029 & (2) 0.000 \\
\hline & 類型 & B & $\mathrm{A}$ & $\mathrm{D}$ & $\mathrm{D}$ \\
\hline \multirow{3}{*}{$\begin{array}{c}\text { 紀伊 } \\
\text { 水道西 }\end{array}$} & 評点 & 46.4 & 夏 80.0 & 10.011 & (1) 0.031 \\
\hline & & & 通 86.7 & 駅 0.028 & (2) 0.036 \\
\hline & 類型 & B & A & D & D \\
\hline 海部灘 & 評点 & B & $\mathrm{B}$ & $\mathrm{D}$ & $\mathrm{D}$ \\
\hline 土佐湾 & 評点 & A & B & D & D \\
\hline 紀州灘 & 評点 & $\mathrm{A}$ & $\mathrm{A}$ & A & C \\
\hline
\end{tabular}




\section{a) 気象条件}

気象条件は、土位湾以外の全ての沿岸域において Bである。季節変動の大きい沿岸や、冬期での気象条件に問題を 持つ沿岸などがこのタイプに属する。徳島県の沿岸域はこの傾向が曊著であり、沿岸域を利用するには、この点を十 分考慮する必要がある。ただし、全国の沿岸の分析結果によると、Bと評価される沿岸域む多く、徳島県の気象が際 だって悪いわけではない。一方、徳島県の対岸に位置する紀州灘の沿岸の気象条件はAである。したがって、海洋性 レクリエーション用途として徳島県の沿岸域を開発する場合、紀州灘沿岸とは異なる、独創性の豊かなものを造る必 要があろう。

b) 波浪条件

太平洋纪面している蒲生田岬以南の海部灘は、海洋性レクリエーションのもっとも盛んな夏期での利用に問題があ る Bである。しかし、蒲生田岬以南の瀬戸内海に面している紀伊水道内の沿岸は、活動的なダイナミックなマリンス ポーツの活用を図る上で最むよい条件であるAである。海部灘では、海水浴場としての利用以外の方法を考えたり、 苛るいは積極的に波や流れを制御する施設、たとえば海域制御構造物などを建設することによって、波浪の静穞化を 図るなどの開発目的を明確にした活用方法を採用すべきであろう。このように、徳島県沿岸の波浪条件が地区によっ て大きく異なるが、これはかえって、沿岸域の開発を行うに当たり幅広い選択枝を持つことになり、適当な方法を考 案すれば多種の開発の可能性を秘めていることを示唆している。

c）交通の整備状況による分類

紀州潅のA、伊予灘のB以外は全てDであった。全国の沿岸域を見てもDに分類される沿岸域は限られている。こ のような交通状況では、徳島県の沿岸域を通常の方法で開発することは困難であると言える。前に述べた、交通機関 に対する県民の世論も考慮すると、沿岸域だけにとどまらず交通機関を早急浽整備することが望まれる。

d）開発地としてのポテンシャルによる分類

開発地としてのポテンシャルの評価は、紀州灘を除いた全ての考察対象地点でDであった。このことは、四国 4 県 とむ、全国的視野でみれば相対的に人口の增加がなく、都市が形成されにくいこと、観光資源が少ないことを意味し ており、各県の独自性を発揮する以前に四国全体の開発ビジョンを明確にすることが、必要があるように思われる。

e）レクリエーション施設数による分類 四国4県と和歌山県で評価を行った結果を示した表-11から、全て の項目で香川県と和歌山県が $\mathrm{A} 、$ 徳島県はBであることがわかる。 今回は、2段階で評価したために、明確に他県との差異や徳島県の 特性を見るには至らなかった。

\section{4. 結言}

本研究では、徳島県の沿岸開発にあたり、各地域の個性を生かしつ つ、広域的な視野で沿岸を利用するための方向性を模索したものであ る。そこで、徳島県の県民意識、社会環境、自然環境の実態把握に努 めた結果、四国全域が全国レベルでみて、社会環境面で優れていると

表-11 レクリエーション施設数による各県の分類

\begin{tabular}{|cc|c|c|c|c|}
\hline & 山岳 & 海洋 & レ゙ャ- & 自然探勝 \\
\hline 徳 & 島 & B & B & B & B \\
\hline 香 & 川 & A & A & A & A \\
\hline 愛 & 媛 & B & B & A & B \\
\hline 高 & 知 & B & B & B & B \\
\hline 和歌山 & A & A & A & A \\
\hline 大 & 阪 & A & A & A & A \\
\hline 兵 & 庫 & A & A & A & A \\
\hline 岡 & 山 & B & B & B & A \\
\hline
\end{tabular}

は言えないこと、また、徳島県は近隣諸県と比べて、社会観境、自然環境とも特别氾恵まれているわけではないこと を明らかにした。さらに、自然・社会環境から徳島県沿岸を評価すると、徳島県沿岸域の開発ポテンシャルは必ずし も高くないことがわかった。しかしながら、全国レベルで一律に評洒する評檤手法の妥当性にも疑問があり、都市型 の開発を指向しない、別の開発手法を開発すべきであうう。したがって、潜在的な開発のポテンシャルをどのように 活かすかが、今後の問題である。

最後に本調查および研究にあたり全面的にご協力を得た、元学部生の野尻敦子女史に感謝の意を表する。

\section{<参考文献>}

1） N H K 放送世論調査所：全国県民意識調查，pp.69-72,1979

2） 徳島県：県民世論調査報告所，1990

3）徳島県企画調整部統計課：統計でみる徳島県民の暮らし,1986

4）徳島経済研究所：暮しと経済, No. 8,1990

5）徳島県観光物産課：徳島県観光調査報告所，1989

6）宇多孝明・村井禎美・武中伸之：海洋利用空間創世のための適地選定手法の検討，海洋開発論文集，vol.4 ,pp.219-224,1988

7）宇多孝明・村井禎美・武中伸之：海洋性レクリエーションの適地基準からみた全国沿岸域の類型化, 海洋開発論 文集, vol.5,pp.125-130,1989 